\title{
THE PRODUCTION OF LEISURE FOR METROPOLES AND COUNTRY HOUSE CONDOMINIUMS
}

\author{
a produção do lazer para a metrópole e condomínio de chácaras
}

\author{
Tadeu Alencar Arrais *
}

\begin{abstract}
Resumo
Os estudos sobre os ambientes metropolitanos tradicionalmente versavam sobre os arranjos institucionais, as dinâmicas de mobilidade/centralidade e os deslocamentos da população de baixa renda para a franja metropolitana. Essas perspectivas de análise associavam-se ao reconhecimento do crescimento das metrópoles e seu transbordamento para a periferia, o que atribuiu centralidade à preocupação com a produção do espaço. A discussão sobre o lazer, por sua vez, ganhou destaque com a modernidade, no que se convencionou chamar "lazer de massa". O lazer começou a ser compreendido, nessa concepção, a partir da relação com o trabalho, motivo pelo qual sua genealogia remonta à Europa urbana e industrial do século XIX. Surgem, a partir dessas aproximações, duas proposições que permitem reconhecer a simbiose entre metrópole e lazer. A primeira é a de que a urbanização, associada à evolução dos meios de transporte, aumentou a demanda pela produção de espaços de lazer. A segunda é a de que as atividades de lazer exigiram arquiteturas funcionais para servir, especialmente, aos interesses dos grupos abastados. Ao mirar a análise na produção do espaço, enxergamos o lazer como atividade programada pelos atores ligados ao mercado imobiliário, que se aproveitam dos estoques de terra fora do polo metropolitano para implantar condomínios de chácaras para segunda residência.
\end{abstract}

Palavras-chave: Metrópole; Lazer; Condomínios de chácaras

\begin{abstract}
Studies on metropolitan environments have traditionally focused on institutional arrangements, on mobility/ centrality dynamics, and on the commutes of the lower classes to metropolitan fringes. These analytical perspectives stem from acknowledging the growth of metropoles and their suburban sprawl, factors which made the concern over the production of space a central topic of debate. Discussing leisure, in turn, gained renown with the advent of modern times, being commonly referred to as 'mass leisure'. From this perspective, leisure began to be viewed in its relationship to work, which is why its origins can be traced back to nineteenth-century urban and industrial Europe. Two propositions stemming from this relationship make it possible to endorse the metropolis and leisure symbiosis. The first is that urbanization, combined with the evolution of transportation, increased the demand for leisure spaces. The second is that leisure activities required functional architectures that mainly served the interests of wealthy groups. By focusing on the production of space, this paper regards leisure as an activity programmed by real estate actors, who take advantage of land stocks available outside metropolitan centres to establish country house condominiums as second homes.
\end{abstract}

Key words: Metropolis, Leisure, Country House Condominiums

\section{Resumen}

Los estudios sobre los entornos metropolitanos, tradicionalmente, han versado sobre los arreglos institucionales, las dinámicas de movilidad/centralidad y los movimientos de la población de bajo ingreso para la periferia metropolitana. Estas perspectivas de análisis se asociaron con el reconocimiento del crecimiento de la metrópoli y su propagación a la periferia, lo que se convierte en una preocupación con la producción del espacio central. Ya la discusión sobre el ocio ganó centralidad a través de la modernidad, que es convencionalmente lhamado "ocio de masa". El ocio comienza a ser entendido, en esta concepción, por medio de su relación con el trabajo, por lo que su genealogía se encuentra en la Europa urbana y industrial del siglo XIX. Surgen, a través de estos enfoques, dos propuestas para el reconocimiento de la simbiosis entre la metrópoli y el ocio. La primera es que la urbanización, junto con la evolución del transporte, he aumentado la demanda de producción de espacios de ocio. La segunda es que las actividades de ocio se requieren arquitecturas funcionales que sirven, sobre todo los intereses de los grupos ricos. Al mirar el análisis en la producción del espacio, vemos el ocio como una actividad programada por los actores vinculados al mercado inmobiliario que se aprovechan de las areas fuera del polo metropolitano para la implantación de condomínios cerrados de chacras para segunda residencia.

Palabras clave: Metrópoli, Ocio, Condominio cerrado de Chacras.

$(*)$ Lecturer, Doctor of the Federal University of Goiás (Universidade Federal de Goiás) - Conjunto Itatiaia, CEP: 74630040, Goiânia, (GO), Brasil. Tel: (+55 62) 5211170 - tadeuarraisufg@gmail.com 


\section{INTRODUCTION}

Metropolis and metropolization are related terms, but not equivalent ones. Hence, it is not common to use one without referring to the other. Metropolization designates, most often, a hierarchical structure, i.e. the protagonism of a metropolis which exerts centripetal force on surrounding areas. The metropolis' economic centerpiece is translated by the centrality of industries or tertiary activities. Furthermore, it performs political and administrative functions. These features determine the metropolis' relation with its immediate surroundings, turning the latter into complementary spaces for the expansion of industry and the real estate market, as well as into workforce stocks. The concept of metropolization, therefore, refers to these non-fitting spaces between institutional borders and the movement of economic and social forces.

Attempting to define or classify the metropolis is not a recent trend. Classical studies on urban ecology, for instance, have long expressed such a concern. Researchers were interested first in metropolitan centres and, later, in the complementarities between metropoles and metropolitan suburbs.

However, the analysis of contemporary metropolization still faces several challenges, especially as regards acknowledging the various metropolitan spatial patterns that distance us from the subordination narrative of peripheral spaces, which have become increasingly complementary. Lencione (2013) states, among other topics, that examining the land market within the metropolization process makes it possible to understand the dispersed land pattern. This is an interesting argument because the analysis of spatial patterns helps us to establish the differences between metropolis and metropolization. The spatial pattern imposed by metropolization is, in a way, the translation of the integration of the land market, particularly in metropolitan municipalities, a process determined by the metropolis' various economic and social demands. The most notable example is the fragmentation of urban and/or rural space in metropolitan municipalities, marked by discontinuity and the presence of enclaves.

These enclaves are characterized by factories and lower-class settlements as well as by a set of leisure activities, e.g. fish \& pay establishments, farm hotels, party rental locations and, which is of particular interest in this paper, country house condominiums. Such discontinuous territorial pattern operates from within the metropolis, which can be confirmed by the structure of the road system as opposed to the metropolitan space's differentiated real estate value increase. Hence complementarity is always hierarchical, given that the metropolis gathers and disperses capital surplus. Harvey (1980, p. 204) puts forward a relevant analysis in this regard: 'Cities are built forms created out of the mobilization, extraction, and geographic concentration of significant quantities of the socially designated surplus product'.

According to Harvey (1980), cities feature favourable conditions for surplus accumulation, among them populational concentration, easy communication, high productivity, etc. Surplus is drained and reinvested in the productive, financial, and real estate markets (real estate circuit and/ or land circuit) for profit gain or savings. In metropolitan fringes, land becomes an accumulating factor for real estate actors settled in the metropolis. The premise that capital circulation also implies spatial movement (Harvey, 2011) illustrates this drainage of income.

The favourable conditions mentioned by Harvey continually create a spatial demand for several activities, including leisure. The artificial spatial limit within the metropolis makes space supply, which previously accounted for industrial expansion, for instance, a decisive element for new forms of housing associated with leisure. This, however, does not occur randomly because the location of such areas possesses certain qualities, such as the availability of large and cheap rural plots and of highways that allow access to certain fractions of the metropolis. Other amenities, such as plant cover and water, are easily put in place by entrepreneurial urbanism. The production of these spaces, as will be discussed further on, accounts for a set of metropolis-related leisure activities. 


\section{SECOND HOMES AND THE PRODUCTION OF LEISURE SPACES}

Are leisure spaces produced within the metropolis or for the metropolis? If one accepts the notion that production involves a set of representations that exceed the material scope, then it is safe to say that both statements are correct. Within the metropolis, negative representations are created, encouraged, and reproduced, resulting in the emergence of needs associated with private leisure which demand spaces that provide security and abundance of 'nature'. These architectural spaces, known as country house condominiums, meet the needs of the metropolis, i.e. they exist for the metropolis.

The link between leisure and cities is not new. This is not to say that the former sprang from the latter, but only that, in distinct historical periods, particularly with the rise of industrial cities throughout Europe, it was strongly influenced by the demands posed by urbanization (Urry, 2001). A result of willingness and the availability of free time, leisure also stems from a set of cultural mediations which called for the construction of specific spaces intended for its activities. Leisure belongs, therefore, to a world marked by the fragmentation of time and space. As a cultural practice, it is linked to each historical period in a different way. As a spatial practice, it functionalizes and creates, in every historical period, spaces that seek to provide a unique experience. This was the case with Roman villas and European seaside and mountain resorts, and can be seen today in tropical resorts.

Firstly, leisure required spatial structures which involved producing space. This statement, on the one hand, strips leisure of the status of mere individual choice and, on the other, locates it historically, extracting its centrality from modernity and from its opposition to work. In a classic essay, Dumazedier (2008) locates the birth of leisure in the Industrial Revolution. According to him, leisure is not 'laziness, it does not suppress work; it implies work. It amounts to an occasional release from work at the end of the day, the week, the year, or a lifetime' (Dumazedier, 2008, p. 28).

Such a notion is natural, given its close ties with analyses of modernity; to use Arendt's (2014, p. 5) expression, it is grounded on a 'theoretical glorification of work'. This glorification had time as its central element and the metropolis as a place of manufacturing work. Factories were regarded as places to discipline bodies based on some sort of time economy. By alluding to the London scene, Thompson (1998, p. 272) stresses that time 'is now currency: it is not passed but spent'.

Time discipline required spatial structures within factories and cities, as well as in the surrounding areas. Mines, factories, tenements, and railways were, according to Mumford (1998), agents of change in rising cities which imposed a brand new experience of time and space. Time-related gains - a result of historical struggles for the reduction of working hours, the right to a weekly rest, the holiday policy, etc. - were, in short, urban gains which called for the construction of leisure spaces. In Rybczynski's (2000) assessment, the new time structure affects both when and how we rest. Moreover, it also affects where we rest.

Lefebvre (2006) claims that, by fully apprehending a given space, it is possible to understand the spatial practices of a social group. In his work, he discusses how the Mediterranean Sea met the leisure-oriented demands of industrial Europe based on the manipulation of space. Seaside holidays, during that period, were sought in the wake of new forms of sociability and pleasure. The empty territory (the sea), often associated with fear or healing hopes (Corbin, 1989), was refunctionalized to welcome, from time to time, a mass of sun and seabathing enthusiasts who attempted to escape both the smog and the spleen. Cities were, undoubtedly, the major place of origin of this apparently homogeneous crowd who periodically sought fields, seaside resorts, beaches, mountains, and campsites in order to spend their free time.

The notion of second home, a space that is both private and formally distinct from one's main home, refers to a place in which free time is spent and the owner's privileged financial status is exposed. Second homes are the object of analysis in many countries (Aledo Tur, 2008; Contreras, 2010; Hiernaux, 2005), Brazil ranking among them (Dantas, 2009, 2011; Assis, 2012; Fonseca, 
2012; Arrais, 2013). In conceptual terms, some researchers - Tulik (2001), for instance - claim that a second home is a kind of tourist lodging. If it is indeed to be conceived of as residential tourism, then its owners may be seen as tourists, regardless of the spatial context or the commuting radius. Fonseca and Lima (2012) describe the differences between a tourist and a second home user by highlighting the emotional ties, the neighbourhood scenario and sociability as factors that distinguish them.

In Brazil, all studies concerning second homes employ data from the Instituto Brasileiro de Geografia e Estatística - IBGE (2011), a governmental body that defines this type of housing as occasional, to be used at weekends or during holidays. In 2010, there were 3,932,990 houses for occasional use in Brazil (Instituto Brasileiro de Geografia e Estatística, 2010), which amounted to $5.82 \%$ of the total of housing units. The most significant housing concentrations are found in coastal areas, mainly due to seaside holidays. However, this phenomenon has also been registered in the Brazilian hinterland.

Two factors explain the spatial dispersion pattern of second homes in Brazil. The first refers to the environmental conditions of municipal sites. Areas close to water, whether they are beaches, riverbanks or dams, show high numbers of second homes. The municipalities of Porto Rico (PR) and Ibiúna (SP), growing along the banks of the Paraná river and the Itupararanga dam respectively, are examples of this process. In 2010, 26\% and 27\% of houses were classified as occasional-use units in both cities respectively. Scenic terrains, particularly in mountainous areas, also account for the large number of second homes within the total number of housing units. Teresópolis and Petrópolis, located in Rio de Janeiro State, totalled 20,606 houses for occasional use in 2010. In the words of Dias (2013), both cities have been traditional holiday locations since imperial times.

The second factor which explains the presence of second homes is the proximity between large urban centres and highways responsible for promoting easy access, because commutes take place mostly during the weekends. Therefore, there is an induction area, densely populated and with higher average household income, and a reception area, less populated and with lower average household income. It is widely known that the average monthly income of people aged 10 or over (with incomes) in metropolitan capitals is always higher than the income of cities with a greater concentration of second homes in the same metropolitan arrangement. In Greater Vitória, the difference between the capital's income and that of the municipalities with the highest relative proportion of second homes reaches 2.17 in favour of the metropolitan centre. In Greater Recife, the capital's average monthly income is 3.03 times higher than that recorded in municipalities with the highest concentration of second homes (Arrais, 2014).

In 2010, Brazil's 39 metropolitan regions concentrated 1,402,388 occasional-use housing units, amounting to $35.6 \%$ of the country's total (Instituto Brasileiro de Geografia e Estatística, 2010). This piece of data, albeit significant, fails to confirm the hypothesis outlined in this study by not revealing owners' place of residence. Researchers like Tulik (2001), Macari (2009), Dantas (2011), Batista (2012), and Lima (2014), among others, provide occasional references on the relationship between realty ownership and properties' centralization in metropoles and/or medium-sized cities.

Real estate control of second homes is performed in four scales. The first is intramunicipal, demonstrated by property owners travelling to country houses located in the outskirts of the cities where they live. Even capitals still possess rural land stocks used as properties for leisure. In São Paulo State, for instance, nearly $14 \%$ of the territory is made up of country areas (Sistema Ambiental Paulista, 2014). The second scale is intrametropolitan, shown by properties located in a radius of $60 \mathrm{~km}$ or more from the metropolitan centre. Commuting to Rancho Queimado, in Greater Florianópolis, fits into this particular scale. In 2010, 31\% of its housing units were classified by IBGE as occasional-use. The third scale is state-regional, resulting from a broader commuting radius. An example is the commute of paulistanos, or São Paulo residents, headed for condominiums in Joanópolis, São Paulo State, in the vicinities of the Jaguari dam, located $108 \mathrm{~km}$ from the capital. Further examples include Icapuí, located 120 km from Fortaleza, Ceará State, and Xangri-Lá, lo- 
cated $131 \mathrm{~km}$ from Porto Alegre, Rio Grande do Sul State. According to IBGE, 71\% of houses in Xangri-Lá were of occasional use in 2010. Lastly, the fourth scale is international, more evident in coastal areas. Ownership of second homes by European citizens warrants special attention, even though this particular market is highly sensitive to economic crises.

\section{COUNTRY HOUSE CONDOMINIUMS AND THE SEARCH FOR THE 'LOST NATURE’}

In Brazil, condominiums of country houses and/or small farms for leisure are characterized by large, fenced expanses of land located in metropolitan municipalities and divided into plots - the country houses and/or small farms - which exceed the traditional urban building height limits. They are private spaces for leisure located in country areas or in discontinuous urban areas where second homes predominate. They are, therefore, sparsely populated. The terms 'country house and/or small farm', albeit distinct in terms of area size, work relations, and production system when compared to the more traditional country houses and/or small farms, particularly in Brazil's Central-West region, are often encouraged by the real estate market and accepted, without hesitation, by the owners of condominium plots. Before further examining the hypothesis that expanding this type of urban settlement meets the metropolis' demand for leisure, two issues must be brought forward.

The first issue concerns the legality of condominiums located in rural areas. For the purposes of this paper, it is sufficient to state that a considerable number of these establishments are irregular in terms of land property, i.e. many of the country houses in them do not have property deeds. Considering Law 6,766, passed on December 19, 1979 (Brasil, 1979), which regulates land subdivision, the very definition of gated communities, even in urban areas, is subject to discussion (Souza, 2008; Rua, 2013). The subdivision of rural areas is, in turn, regulated by Law 4,504, passed on November 30, 1964 (Brasil, 1964), and by Law 5,868, passed on December 12, 1972 (Brasil, 1972). The 1964 legal text defines country real estates, in Article 4, in terms of the presence of 'agricultural, cattle-raising or agroindustrial extractivist exploration', as well of their location in urban or country areas. Article 65 stresses that a rural property is not 'liable for division into areas whose dimensions are inferior to that constituting the rural property module.' Hence, the current regulation on the subdivision of rural properties is grounded on what the Instituto Nacional de Colonização e Reforma Agrária (Incra), Brazil's National Institute for Colonization and Agrarian Reform, has called Fração Mínima de Parcelamento (FMP), or Minimum Subdivision Fraction, which amounts to the exploration module of agricultural and livestock produce (Instituto Nacional de Colonização e Reforma Agrária, 2014). In the cities which make up Greater Goiânia (RMG), the FMP totals two ha (Instituto Nacional de Colonização e Reforma Agrária, 2014) or 20,000 square metres. This legal definition confers to most country house condominiums, thus, illegal standing, which is quite functional for landowners since the Imposto Territorial Rural (ITR), or Rural Land Tax, continues to affect the entire subdivided rural plot. In one of the establishments investigated, a 54-ha area located in Bela Vista de Goiás, the ITR due in 2014 totalled 43 reais, according to the building manager.

The second issue concerns the representation of the countryside divulged by the real estate market. As Williams (1989) teaches us, the country and the city have always been linked to a set of contradictory emotional attitudes. The country as a natural form, marked by 'simple virtues', and the city as a centre of achievement have comprised positive representations since Classical Antiquity. On the other hand, as Williams points out, the city's 'worldliness and ambition' has evolved alongside the 'backwardness and ignorance' of the country. Country, hence, became the negation of the city. Such a representation illustrates the impacts of factories' means of production and time appropriation regime during the nineteenth century.

Both the notion and the experience of time have changed radically, which has negative impacts on the rural population. The non-fit between the factory's productive and disciplinary time and the country's productive, season-mediated time is able to define the political tensions in Victorian En- 
gland (Williams, 1989; Thompson, 1998). Howard (2002) acknowledges such tensions and condemns the city and the country together, proposing instead what has become known as garden cities. His Three Magnets diagram is both a complete denial of the city and a romantic reconstruction of a new harmonious world. This is a crucial viewpoint, because from it, one may claim, stemmed the very idea of suburb. The rural representation which now comes forward conveys an idealized image, in the way of a conflict-free environment with an untouched nature, where life is produced and reproduced in a unique way.

Although several studies have focused on the expansion of country house condominiums with the status of second homes in metropolitan environments, for instance those of Macari (2009) and Lima (2014), research in this field usually concerns second homes in seaside locations, even if only individual housing units are examined. Macari's (2009) thesis on the municipality of Rancho Queimado, in Greater Florianópolis, showed that 22 gated establishments occupied 5.05\% of the municipal territory. Campos Júnior and Bergamim (2007) estimated that country house condominiums in four municipalities of Espírito Santo State's highlands occupy an area of approximately 5,000,000 square metres. Lima (2014) designed a cartography of the development of country house condominiums in the RMG, highlighting the roles played by real estate actors. From a different perspective, but acknowledging the centrality of the land issue, this paper analyses country house condominiums in Greater Goiânia based on three parameters. The first is position, which means verifying a given location in view of centrality. The second is urbanism, which requires analysing aspects linked to security and urbanization. The third is daily life, which demands considering the forms of appropriating space and the conflicts resulting from such appropriation. Data collection and mapping took place during the second semester of 2014 and the first semester of 2015 and were based on testimonies provided by building managers, staff members, real estate agents and, in lesser number, property owners. In some condominiums, we were given access to house rules and to the minutes of condominium meetings.

The concept of position, the first parameter of this analysis, is linked to the issue of centrality. Spósito and Góes (2013, p. 121) claim that centrality 'is the relationship between spaces with higher density of means of consumption, be they collective or individual, and what these spaces represent in terms of historical and symbolic value, as well as the possibilities of accessing them'. The most effective centrality is that which allows landowners access to consumption equipment located in the metropolis, hence affecting the commercial value of country houses. The relationship between large stocks of country areas and access to the most valued parts of the metropolitan centre via dual carriageways influences the offer of country house condominiums. Bela Vista de Goiás and Hidrolândia have the largest stocks of rural areas in the RMG - 130,043 ha and 90,807 ha respectively (Instituto Nacional de Colonização e Reforma Agrária, 2010). In addition, both have access to Goiânia's south and south-west regions via dual carriageways (GO-020 and BR-153), these regions being the most valued by the real estate market. Of the 39 condominiums researched, eighteen are located along these carriageways and/or in areas which offer access to them, occupying around $17,530,135$ square metres. Accessibility, defined as a favourable condition for setting the metropolis' centrality in motion, accounts for such a location, given that leisure-oriented commuting usually takes place on weekends, not only during holidays or extended public holidays.

The largest condominiums occupy areas of over 1.8 million square metres, such as Alto da Boa Vista (in Senador Canedo), Encontro das Águas, and Águas da Serra (both in Hidrolândia), whose respective areas total 1.9 million, 2.9 million, and 4.1 million square metres. The smallest establishments by area are Bela Vista (in Santo Antônio de Goiás), Dolce Vitta (in Hidrolândia), and Nova Itália (in Nova Veneza), totalling nearly 90,000, 182,000, and 217,000 square metres respectively. The offer of internal areas depends on a condominium's dimensions. Águas da Serra, the largest, has six hundred plots, whereas Ribeirão das Cachoeiras, the smallest, has 37 plots. Extensive areas also allow the presence of green space, lakes and recreational spaces, e.g. football fields, attributes which favour, at least in theory, collective use. According to information conveyed by descriptive 

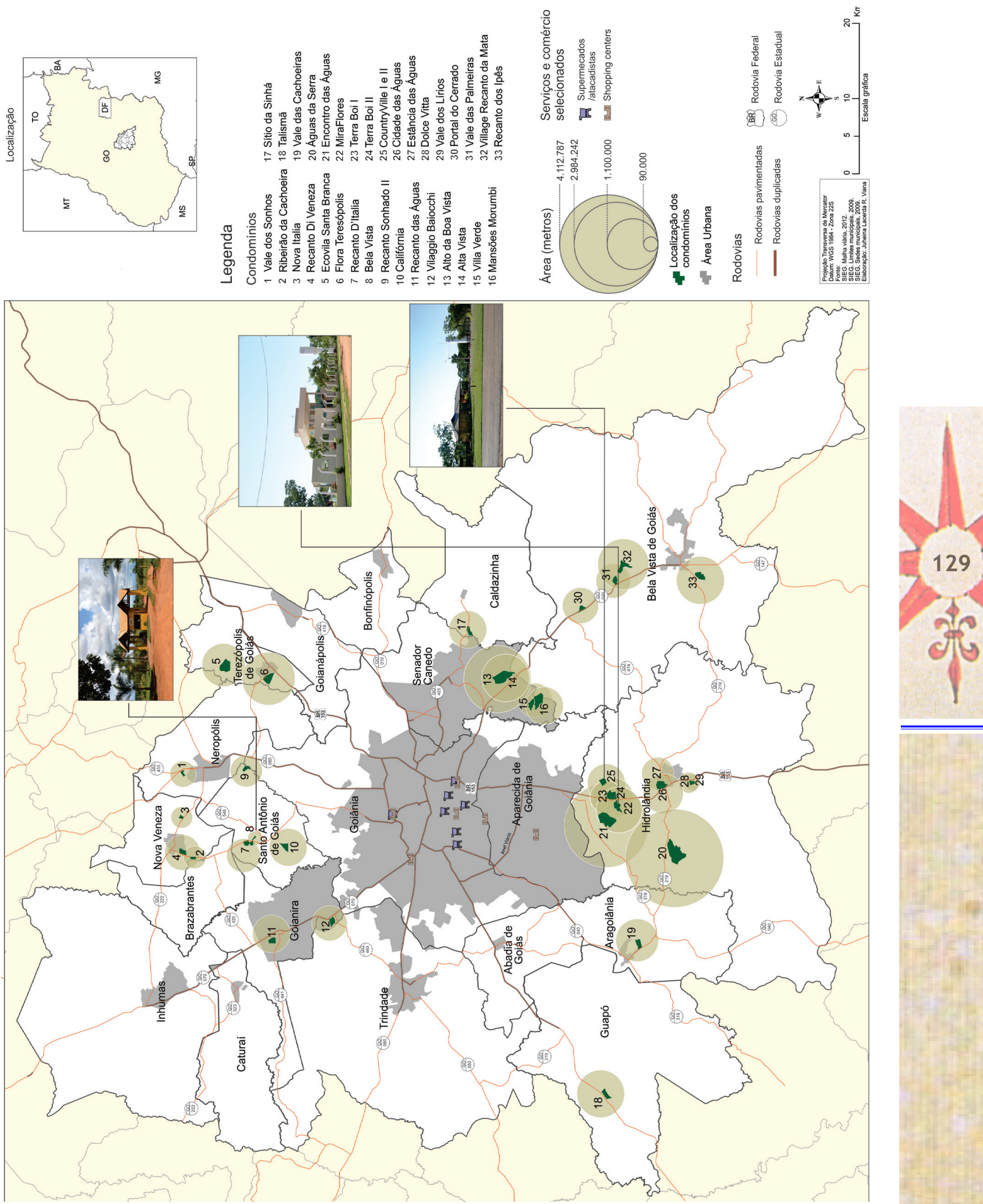

Figure 1 - . Location and area of country house condominiums in Greater Goiânia 
memoranda, the Águas da Serra condominium has approximately 1,000,000 square metres of green space, whereas Village Recanto da Mata has 316,000 square metres of native forest.

Urbanism, the second parameter of the present analysis, implies, as Lefebvre (2008) claims, a global strategy of production of space. Not by chance, there are symmetries between country house condominiums and urban condominiums. Such form of urbanism may be examined in terms of external and internal scales. In the first, security is the chief element, demonstrated by brick walls, wire fences, and a set of devices similar to the ones described by Caldeira (2000). The external morphology reveals that security is not a service but a form of urbanism, an amenity as important as nature or quality of life. The idea of tranquility is not associated with appropriating the pace of country time, but rather with the possibility of private security. The latter is, hence, sine qua non for leisure activities. Patrols, internal fencing, watchdogs, alarms, etc. reproduce the security systems commonly found in urban neighbourhoods. These condominiums, despite being located in rural areas and/or discontinuous, sparsely populated urban areas of expansion, translate an 'architecture of fear', to recall an expression proposed by Bauman (2009).

In spite of occasional reports of thefts and acts of vandalism, security remains a constant demand during condominium meetings, as may be seen in the minutes of meetings held at Portal do Cerrado, in Bela Vista de Goiás, and Villa Verde, in Senador Canedo. The guard stationed at a condominium in Senador Canedo reported six thefts and/or attempted thefts in residences of the neighbouring establishment. A certain amount of competition may be verified in the depreciative reports given by staff members regarding condominiums located in the vicinities. Adopting security measures (night patrols, radio communication system, electric fencing, etc.) remains, nevertheless, a source of costs to the condominiums, leading to frequent complaints by the owners of unbuilt areas. Of the 39 condominiums surveyed, 32 have a 24-hour reception desk and nineteen have a periodical motorcycle patrol. The greater the establishment's occupancy rate, the more visible these security mechanisms are, reducing the costs of hiring specialized firms.

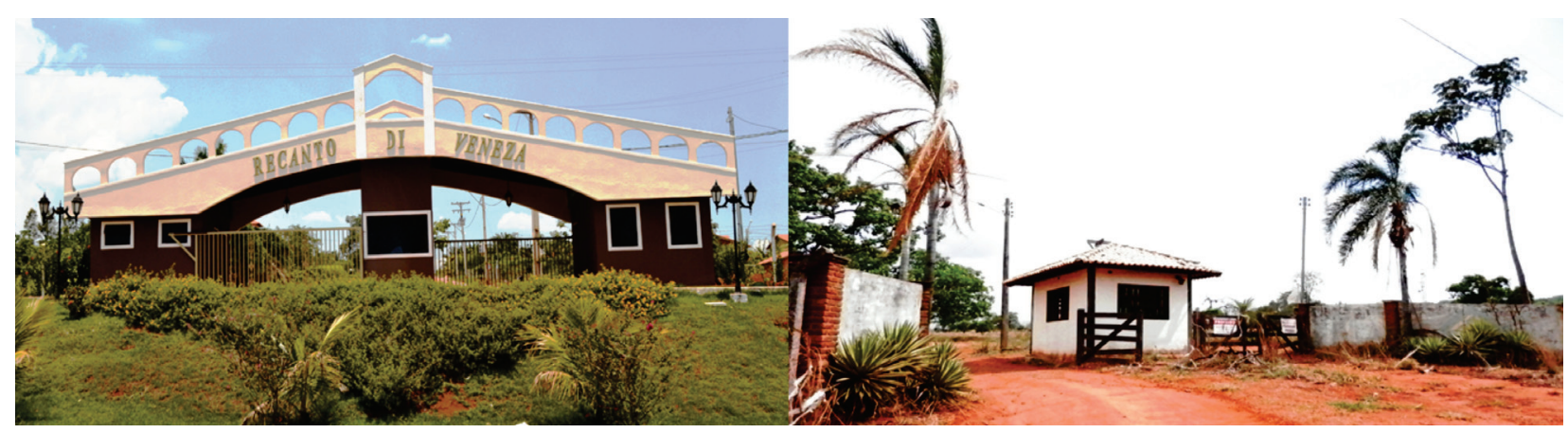

Figure 2 - Façade of condominiums Recanto di Veneza, in Nova Veneza, and Valle dos Lírios, in Hidrolândia Source: Lima (2014).

In an internal scale, on the other hand, urbanism fails to present anything new. Its first act, ironically, involves putting an end to long-standing rural uses. Some of the condominiums are located in old pasture areas and, therefore, little of the original plant cover remains. Hence, urbanism seeks to create spaces that simulate a primary relationship with nature, which justifies investments in toponymy and, furthermore, expresses a certain degree of topophilia (Tuan, 2000). Ten of the condominiums investigated include the words 'water' or 'valley' in their names: Vale dos Sonhos (Valley of Dreams), Estância das Águas (Water Ranch), Água das Serras (Highland Water), Valle dos Lírios (Valley of Lilies), Ribeirão das Cachoeiras (Waterfall Stream), etc. Other toponyms refer to the names of old farms (Califórnia, Talismã, Terra do Boi I and II, etc.) or, as regards those located in Nova Veneza, to the Italian colonization (Recanto Di Veneza, Nova Itália, and Recanto Di Itália). Once toponymy has been defined, urbanism aims to regulate space by promising investors amenities like perimeter fencing, road construction, and energy and water supply. Such facilities, 
found in most condominiums, are closely related to leisure because country leisure cannot spare urban commodities. In this regard, there are few differences between these establishments and their urban counterparts, with the exception of sewage collection and streamflow. Septic tanks with sumps is the most common system used, whereas pluvial drainage via combined sewers is less common. The costs of sewer systems, as well as of asphalt or other pavement materials, are higher than investments in energy and water networks. The latter is a central element in commercial marketing. Small streams or dams can be found in 26 of the condominiums investigated. Associating leisure and water is nothing more than an element feigned by the landscape, given that these areas are rarely used as spaces for collective use.

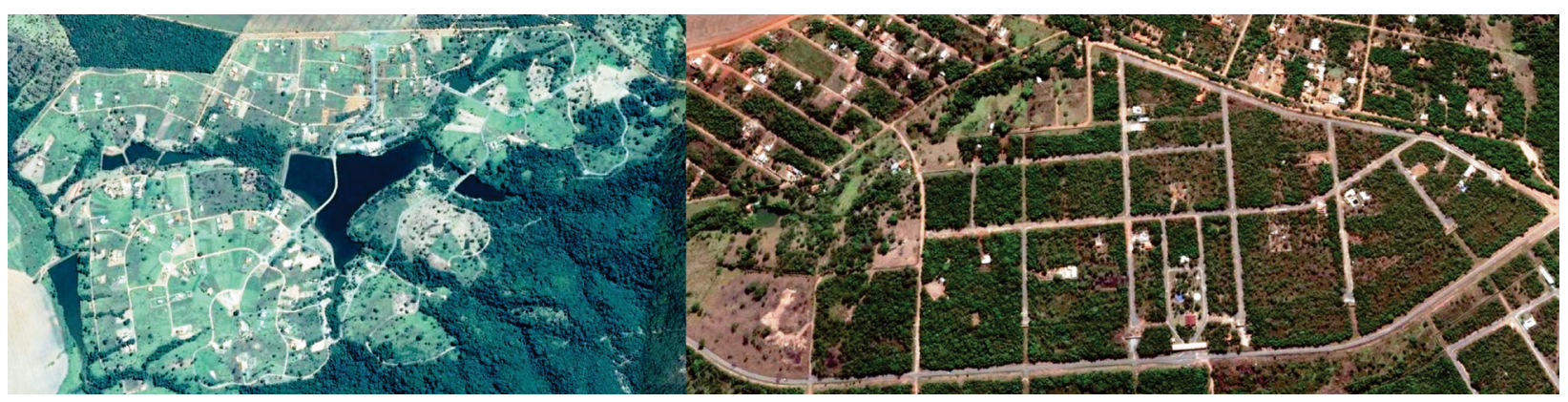

Figure 3 - Condominiums Águas das Serra, in Hidrolândia, and Águas da Serra, in Villa Verde Source: Google Earth (Sept. 2014).

Daily life, the third parameter of this analysis, is undoubtedly the most difficult part of this kind of research because it involves examining different forms of appropriating space; this demands, first of all, an effort to categorise landowners. There are three types of landowners in the RMG: those who live in Goiânia and travel on weekends; those who live in the condominiums themselves, but work in Goiânia; those who own unbuilt areas. Lima (2014) estimates that the occupancy rate of country house condominiums reaches $24 \%$, which indicates that they are sparsely populated. The condominiums with the highest occupancy rates, whether for second or first homes, are Alto da Boa Vista and Alta Vista, Encontro das Águas, Vale das Cachoeiras, Portal do Cerrado, and Recanto das Águas. Even though condominiums show similar urban amenities during the sale stages, there are significant differences between them. There are less internal differences, considering the establishment's standards, than discrepancies between condominiums, particularly concerning centrality. In several of them it is possible to observe a certain degree of popularization, evident in the type of buildings, the precarious forms of access control, and the value of country houses. In one of the RMG's recently built condominiums, Portal dos Ventos, located in Trindade, the construction standard is similar to that normally used in popular housing, even though the marketing strategy divulges pleasant images of the place - which is very distant from reality.

The daily life of second home owners occurs in a specific time (weekends) and space (country houses) where leisure activities take place. It is common to find billboards on both sides of the highways advertising condominiums by bringing forth an idealized representation of the country, one that is always related to security: 'Country houses desired by all and designed for you!', 'Fun, comfort, and security for you and your family', 'The peacefulness of the country combined with everything that you need', 'Leisure, rest, and contemplation'. When asked what the condominiums might offer 'investors', the usual answer given by real estate agents was: 'tranquility and contact with nature.' These amenities seem to oppose the metropolitan experience. Ironically, however, land use planning itself follows that of traditional urban regulations. This stems from the desire to simulate a rural space based on a reality that never existed, whatever the latitude or historical time.

Investigating country houses' internal landscape provides clues that may help us understand the activities carried out on weekends. The first factor that warrants attention is the perimeter fencing around the houses - often made up of wire fences and/or hedgerows -, as shown in Figure 4. 
Within each private area one may see fruit trees, gardens, vegetable patches, small plantations of corn or cassava and, in some cases, the raising of chickens and quails. The houses' average size, often ranging from 1,000 to 5,000 square metres, restricts internal tree planting, particularly due to the presence of swimming pools and small cottages. These features promote - at least in theory the encounter with nature and the country.

Activities are normally restricted to gardening, tending vegetable patches (less common) and a kind of receptive leisure, expressed by welcoming relatives and friends on weekends. Property owners frequently refer to their country houses as 'a place to welcome friends'. In a condominium located in Bela Vista de Goiás, one owner reported her habit of 'making pamonha for friends and relatives.' These activities are normally carried out by owners themselves. Even though the present study did not establish their socio-occupational profile, field observations revealed a majority of liberal professionals and retired individuals. A certain degree of nostalgia was well illustrated by a country house owner in Teresópolis de Goiás, who lives in Brasília but only awaits retirement to 'set in' in order to move to the country for good.

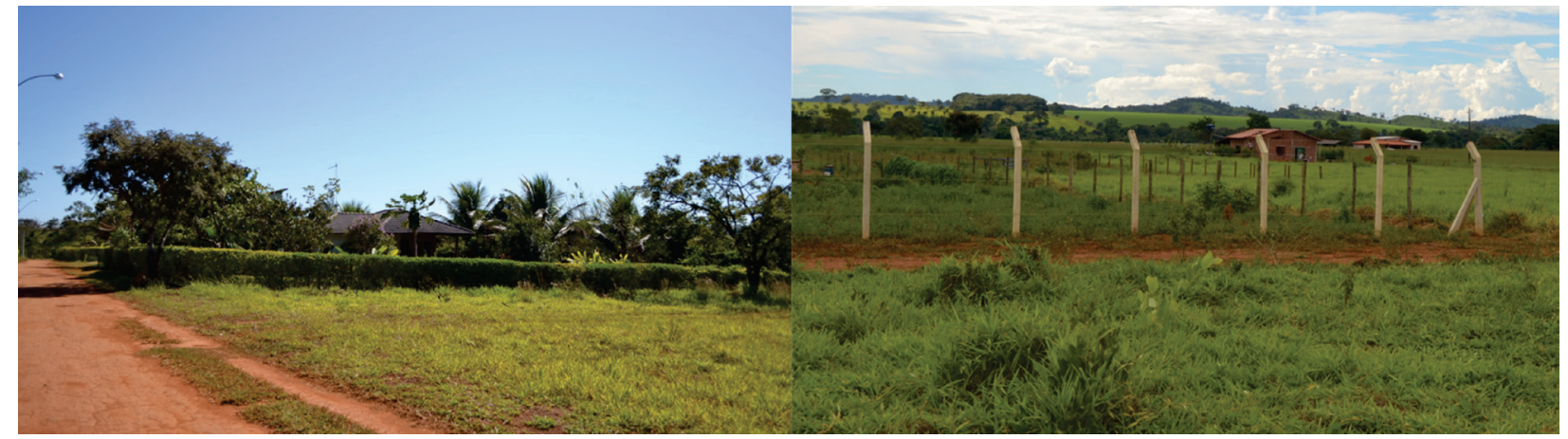

Figure 4 - Internal perimeter fencing of condominiums Portal do Cerrado, in Bela Vista de Goiás, and Portal dos Ventos, in Trindade Images: The author (2015).

Low occupancy rates do not mean that daily life in these locations is not marked by conflict. The most frequent arguments, according to building managers and owners, stem from distinct interests of second or first home owners and of owners of unbuilt areas. Proposals that suggest sharing expenses via fixed investments are generally a cause for complaint on the part of plot owners and/ or investors. Fonseca and Lima (2012) express the two purposes of second homes: to act as a place of rest/leisure and as a profitable investment, in view of the rental market. With regard to country house condominiums, this market appears not to exist, which means that the idea of profitable investment must be relativised. According to a property owner of a condominium from Bela Vista de Goiás, he paid 32,000 reais for his 1,500-square metre country house in June 2010. In April 2015, in his own assessment, the house could be sold for 62,000 reais. A formidable increase in value, so it would seem. However, it is necessary to estimate condominium-related costs, which include sharing investment expenses. In this particular case, the condominium fee totalled 320 reais. Considering the fee's variation since the time of acquisition, one may easily infer that the house's upkeep jeopardised its apparent increase in value.

As far as the dynamics of daily conflicts at the condominiums is concerned, there are two frequent occurrences which take place mostly on weekends. The first is related to noise - complaints about car stereos are made on a regular basis in some establishments. Despite the lack of a rental market, owners often lend their country houses to friends and relatives on festive occasions. This situation results in conflicts between second- and first home owners and even among second home owners. Given that the most ordinary form of leisure does not take place in collective spaces, it is difficult to avoid problems involving general and car stereo noise. There are also complaints about alarms, according to the report of a property owner in Bela Vista de Goiás. Even with all the secu- 
rity apparatus, houses also have electric fences with alarms. These are easily set off, in view of the large numbers of birds and rodents. At a condominium meeting, we observed an unusual complaint about the noise produced by a lawnmower used on weekends. The lawnmower's owner argued that he could only 'mow the lawn', an activity which gave him pleasure, on these particular days.

Raising animals is the second social practice that produces conflict. In two condominiums, we verified the presence of ponies. Most establishments, in fact, do not prohibit pets or other small animals for raising. The issue has raised controversy in a condominium located in Santo Antônio de Goiás because, according to some of the owners, raising animals violates the establishment's ecological philosophy. In addition, as was pointed out in an open letter to associates, there is also the problem of the noise and the walks with the animals. This topic was also debated in a condominium in Bela Vista de Goiás. Conflicts tend to increase as occupancy rates rise.

Due to the type of activities performed, which are not very different from those found in the metropolis, it is possible to infer that country house condominiums offer, instead of a widely publicised escape from daily life, nothing more than an apparent break from it. Contact with nature and the rural environment are, more often than not, simulations which seek to deny urban experience in its fullness but end up reinforcing phobias so typical of our urban model. Condominiums lack an ideal of community capable of shaping an identity, especially if we examine the struggle of interests between first- and second home residents and the owners of unbuilt areas.

\section{FINAL CONSIDERATIONS}

The occurrence and expansion pattern of country house condominiums in the RMG amplifies the effects of space fragmentation in cities and confirms the umbilical link of these establishments with metropolitan centres. Spatial fragmentation corresponds, equally, to income stratification. Leisure comes forth in this process as a strategy for the consumption of space and, therefore, for the increase of profit in the real estate market; it must be pointed out that over 30 million square metres of land in the RMG have thus far been incorporated in the 'country house condominiums' modality. Five key points reinforce this statement:

a) In view of the intense incorporation of rural expanses of land, producing this type of leisure-oriented urban settlement reveals a general trend in the actions of present-day real estate market. Traditionally, the reproduction of space in metropolitan environments has been viewed as a symptom of the demand for popular housing or for the expansion of industrial activities. In today's scenario, marked by the limits of production of space pointed out by Harvey (1980), by the deterioration of quality of life and by the concentration of income in the metropolis, the land stocks of metropolitan cities are used to meet the demand for leisure-oriented second housing, leisure being conceived here as an individual activity linked to certain income standards and to real estate monopoly.

b) Individual leisure, as an undeniable trend, occurs only in private spaces, hence requiring artificial distance from the metropolis. Expanding condominiums threatens the possibility of leisure as a public experience, grounded on urban diversity. Enclave-based leisure, involving large, sparsely-populated spaces, reinforces the characteristics of an intimate society, as evoked by Sennett (1998).

c) The economic effects on municipalities of implementing country house condominiums must be properly examined. It is widely known that owners of both first and second homes establish little contact with the surrounding areas, an attitude which promotes a minor impact in the local economy, considering the consumption of durable and non-durable goods. Interestingly enough, the majority of condominiums in the RMG are located in areas easily accessed by the great wholesalers from Goiânia. Moreover, the metropolitan region lacks a consolidated 
job market for caretakers, given that the security provided by condominiums dismisses such a demand. As regards city management, a considerable number of condominiums, by finding themselves in an irregular situation, are not liable to pay the Imposto Predial Territorial Urbano (IPTU), or Municipal Property Tax.

d) Environmental impacts must be assessed, particularly as regards management and access to water resources. Several gated leisure-oriented establishments expand towards areas close to dams, which makes the use of leisure compete, to some extent, for the water supply - proof of this is the presence of many condominiums in the vicinities of dams in São Paulo State.

e) The spatial arrangement of condominiums, in the heart of rural and/or discontinuous urban areas, while reducing their visibility, is given the status of an isolated process that bears little relationship with the metropolis. However, this model of space production is in fact fully articulated with the metropolitan real estate market, be it because it seeks to reproduce the urban patterns of gated communities, be it because land and real estate commercialization and ownership are centralized in the metropolis. The concept of production of space, as well as surpassing morphology and being grounded on the relationship of condition, means and product of social reproduction proposed by Carlos (2011), helps us to understand both the globality and the local consequences of this phenomenon.

In summary, by distancing themselves from a community ideal, country house condominiums reveal that a focus on leisure is the result of an investment by the real estate market, which promises to offer a unique experience of time and space appropriation in metropolitan outskirts. Such a promise is not fulfilled, however, due mainly to the fact that the production of leisure is restricted to the production logic of metropoles.

\section{ACKNOWLEDGEMENTS}

This paper presents the final results of a research sponsored by CNPq, Human Sciences Public Notice, Batch 43/2013.

\section{BIBLIOGRAPHIC REFERENCE}

ALEDO TUR, Antonio. De la tierra al suelo: la transformación del paisaje y el nuevo turismo residencial. Arbor: Ciencia, Pensamiento y Cultura, v. 184, n. 729, p. 99-113, ene.-feb. 2008.

ARENDT, Hannah. A condição humana. Tradução de Roberto Raposo. 12. ed. Rio de Janeiro: Forense Universitária, 2014.

ARRAIS, Tadeu A. Morar na metrópole, viver na praia ou no campo. Goiânia: Ed. UFG, 2013. Disponível em: <http://www.editora.ufg.br/wp-content/themes/editoraufg/ebook/morar-metropole_viver-praia-campo_ed-ufg.pdf $>$. Acesso em: 25 abr. 2015.

ARRAIS, Tadeu A. Integração do mercado imobiliário e segunda residência: Brasil metropolitano. Mercator, Fortaleza, v. 13, n. 1, p. 49-62, abr. 2014. Disponível em: $<$ http://www.scielo.br/scielo.php?script=sci_ arttext\&pid=S1984-22012014000100049\&lng=en\&nrm=iso>. Acesso em: 24 abr. 2015.

ASSIS, Lenilton F. de. Entre o turismo e o imobiliário: velhos e novos usos das segundas residências sob o enfoque da multiterritorialidade - Camocim/CE. 2012. 278 f. Tese (Doutorado em Geografia Humana) Departamento de Geografia, Universidade de São Paulo, São Paulo, 2012.

BATISTA, Joane L. D. V. Vilegiatura marítima e urbanização em Tibau-RN. In: FONSECA, Maria Aparecida (Org.). Segunda residência, lazer e turismo. Natal: Ed. UFRN, 2012. p. 183-203.

BAUMAN, Zygmunt. Confiança e medo na cidade. Tradução de Eliana Aguiar. Rio de Janeiro: Zahar, 2009. 
BRASIL. Lei $\mathbf{n}^{\circ}$ 4.504, de 30 de novembro de 1964. Dispõe sobre o Estatuto da Terra, e dá outras providências. Diário Oficial [da] União, Brasília, DF, 30 nov. 1964. Disponível em: < http://www.planalto.gov. br/ccivil_03/leis/14504.htm>. Acesso em: 20 abr. 2015.

BRASIL. Lei n ${ }^{\circ} \mathbf{5 . 8 6 8}$, de 12 de dezembro de 1972. Cria o Sistema Nacional de Cadastro Rural, e dá outras providências. Diário Oficial [da] União, Brasília, DF, 12 dez. 1972. Disponível em: <http://www.planalto. gov.br/ccivil_03/LEIS/L5868.htm>. Acesso em: 20 abr. 2015.

BRASIL. Lei ${ }^{\circ} \mathbf{6 . 7 6 6}$, de 19 de dezembro de 1979. Dispõe sobre o Parcelamento do Solo Urbano e dá outras providências. Diário Oficial [da] União, Brasília, DF, 19 dez. 1979. Disponível em: <http://www. planalto.gov.br/ccivil_03/leis/16766.htm>. Acesso em: 28 abr. 2015.

CALDEIRA, Teresa. Crime, segregação e cidadania em São Paulo. São Paulo: Ed. 34: Edusp, 2000.

CAMPOS JÚNIOR, Carlos T.; BERGAMIM, Márcia C. Condomínios fechados na Região Serrana do Espírito Santo, Brasil. Scripta Nova: Revista Electrónica de Geografía y Ciencias Sociales, Barcelona, v. XI, n. 245 (09), 1 ago. 2007.

CARLOS, Ana Fani A. A condição espacial. São Paulo: Contexto, 2011.

CONTRERAS, Luz M. G. La segunda residencia: espacios fragmentados e interconectados. Perspectiva Geográfica, Bogotá, v. 15, p. 113-124, 2010.

CORBIN, Alain. O território do vazio: a praia e o imaginário ocidental. Tradução de Paulo Neves. São Paulo: Companhia das Letras, 1989.

DANTAS, Eustógio W. C. Maritimidade nos trópicos. Fortaleza: Ed. UFC, 2009.

DANTAS, Eustógio W. C. Mar à vista: estudo da maritimidade em Fortaleza. 2. ed. Fortaleza: Ed. UFC, 2011.

DIAS, Cleber. Epopeias em dias de prazer. Goiânia: UFG, 2013.

DUMAZEDIER, Joffre. Sociologia empírica do lazer. Tradução de Sílvia Mazza e J. Guinsburg. São Paulo: Perspectiva, 2008.

FONSECA, Maria Aparecida (Org.). Segunda residência, lazer e turismo. Natal: Ed. UFRN, 2012.

FONSECA, Maria Aparecida; LIMA, Renata M. M. Segunda residência: conceito, características e significados. In: FONSECA, M. A. (Org.). Segunda residência, lazer e turismo. Natal: Ed. UFRN, 2012. p. 11-18. HARVEY, David. A justiça social e a cidade. Trad. de Armando Corrêa da Silva. São Paulo: Hucitec, 1980. HARVEY, David. O enigma do capital e as crises do capitalismo. Lisboa: Editorial Bizâncio, 2011.

HIERNAUX, Daniel. La promoción inmobiliaria y el turismo residencial: el caso mexicano. Scripta Nova: Revista Electrónica de Geografía y Ciencias Sociales, Barcelona , v. 9, n. 194, 1 ago. 2005.

HOWARD, Ebenezer. Cidades-jardins de amanhã. Trad. Marco A. Lagonego. São Paulo: Hucitec, 2002. INSTITUTO BRASILEIRO DE GEOGRAFIA E ESTATÍSTICA (IBGE). Características da população e dos domicílios. Rio de Janeiro, 2010.

INSTITUTO BRASILEIRO DE GEOGRAFIA E ESTATÍSTICA (IBGE). Censo demográfico 2010. Rio de Janeiro, 2011.

INSTITUTO NACIONAL DE COLONIZAÇÃO E REFORMA AGRÁRIA (INCRA). Certificado de Cadastro de Imóvel Rural - nível municipal. Brasília, DF, 2010.

INSTITUTO NACIONAL DE COLONIZAÇÃO E REFORMAAGRÁRIA(INCRA). Perguntas frequentes. 2014. Disponível em: <http://www.incra.gov.br/content/perguntas-frequentes $>$. Acesso em: 20 jan. 2015.

LEFEBVRE, Henri. A produção do espaço. Trad. Doralice B. Pereira e Sérgio Martins. Belo Horizonte: Ed. UFMG, 2006.

LEFEBVRE, Henri. Espaço e política. Tradução de Margarida M. Andrade e Sérgio Martins. Belo Horizonte: Ed. UFMG, 2008.

LENCIONI, Sandra. Metropolização do espaço: processos e dinâmicas. In: FERREIRA, Álvaro et al. Metropolização do espaço: gestão territorial e relações urbano-rural. Rio de Janeiro: Consequência, 2013. p. 17-34. LIMA, Leandro O. A metropolização e o mercado imobiliário: análise da produção do espaço a partir dos condomínios de chácaras da RMG. 2014. 198 f. Tese (Doutorado em Geografia) - Instituto de Estudos Socioambientais, Universidade Federal de Goiás, Goiânia, 2014. 
MACARI, Anelise C. Condomínios fechados em áreas rurais: o caso de Rancho Queimado na Região Metropolitana de Florianópolis. 2009. 216 f. Dissertação (Mestrado em Urbanismo, História e Arquitetura da Cidade) - Departamento de Arquitetura e Urbanismo, Univ. Federal de Santa Catarina, Florianópolis, 2009. MUMFORD, Lewis. A cidade na história. Tradução de Neil R. da Silva. Rio de Janeiro: Martins Fontes, 1998. RUA, J. O urbano no rural fluminense e o preço da terra: continuando a reflexão. In: FERREIRA, A. et al. (Org.). Metropolização do espaço. Rio de Janeiro: Consequência, 2013. p. 383-408.

RYBCZYNSKI, Witold. Esperando o fim de semana. Trad. de Beatriz Horta. Rio de Janeiro: Record, 2000. SENNETT, Richard. O declínio do homem público. Trad. de Lygia A. Watanabe. São Paulo: Comp. das Letras, 1998.

SISTEMAAMBIENTAL PAULISTA (SIGAM). Sistema Integrado de Gestão Ambiental. 2014. Disponível em: $<$ http://www.sigam.ambiente.sp.gov.br/sigam2/Default.aspx?idPagina=7747> . Acesso em: 20 maio 2015. SOUZA, Marcelo L. de. Fobópole. Rio de Janeiro: Bertrand Brasil, 2008.

SPÓSITO, Maria Encarnação B.; GÓES, Edna M. Espaços fechados e cidades: insegurança urbana e fragmentação socioespacial. São Paulo: Ed. Unesp, 2013.

THOMPSON, Edward P. Costumes em comum: estudos sobre a cultura popular tradicional. Tradução de Rosaura Eichenberg. São Paulo: Companhia das Letras, 1998.

TULIK, Olga. Turismo e meios de hospedagem: casas de temporada. São Paulo: Roca, 2001.

URRY, John. O olhar do turista: lazer e viagens nas sociedades contemporâneas. Tradução de Carlos Eugênio M. de Moura. 3. ed. São Paulo: Studio Nobel: SESC, 2001.

WILLIAMS, Raymond. O campo e a cidade. Trad. de Paulo H. Britto. São Paulo: Comp. das Letras, 1989.

Submitted december 2015

Accepted january 2016 